\title{
'N JOHANNESE PERSPEKTIEF OP DIE HUWELIK, GESLAGSROLLE EN SEKSUALITEIT IN 'N POSTMODERNE KONTEKS
}

Author:

Elritia le Roux ${ }^{1}$

\section{Affiliation:}

${ }^{1}$ Departement $\mathrm{Ou}$

Testamentiese Wetenskap,

Universiteit van Pretoria,

Suid-Afrika

\section{Correspondence to:}

Elritia le Roux

email:

leroux.elritia@gmail.com

Postal address:

Posbus 149, Kriel 2271,

Suid-Afrika

Keywords:

onderdrukking; vrou;

post-modern; kerk;

Afrikaner

\section{Dates:}

Received: 08 Jan. 2009

Accepted: 16 Nov. 2009

Published: 29 Mar. 2010

How to cite this article:

Le Roux, E., 2010, "n

Johannese perspektief op

die huwelik, geslagsrolle

en seksualiteit in 'n

postmoderne konteks',

Verbum et Ecclesia 31(1), Art

\#347, 8 pages. DOI: 10.4102 /

ve.v31i1.347

Note:

Artikel voorgelê ter

vervulling van die MA

Bybel- en Godsdienskunde

in die Fakulteit

Geesteswetenskappe aan

die Universiteit Pretoria.

Die promotor is prof. P.

Geyser en mede-promotor prof. D.J. Human

\section{This article is available} at:

http://www.ve.org.za
(C) 2010. The Authors. Licensee: OpenJournals

Publishing. This work is licensed under the

Creative Commons

Attribution License.

\section{ABSTRACT}

The hypothesis offered in this study is that the Johannine texts are authoritative, canononical documents with the inherent potential that is applicable to the practical lives of the faithful. Since Biblical texts are the product of the patriarchal culture within which they originated, a hermeneutic of suspicion becomes essential. In the interaction between the Biblical text and the contemporary context, a creative space is being created which requires a humble attitude from the exegetes to acknowledge the temporary nature of their findings. We need to look past the patriarchal nature and language towards a more inclusive paradigm. The Bible does not bind us to a rigid way of living, but liberates us for the appreciation of the healing power of God's grace in our context. We need to move past stereotypes and to see others through the eyes of Christ. Jesus took a radical stance against the culture of his day. From the beginning of his public ministry, we find in him the tension between his prophetic role and the dominant culture of day. This tension leads to Jesus becoming a marginalised Jew, who stands outside the Jewish inner circle. He does not fit into the conventional social roles of his day. Jesus rather associates himself with the marginalised. This illustrates Jesus' radical commitment to God and his passionate commitment to the truth of the Gospel.

\section{AKTUALITEIT EN RELEVANSIE}

As gevolg van die stewige greep wat die patriargale stelsel op die Afrikaner se kerkwees, kultuur en denke uitoefen, het baie wanpraktyke rakende seksualiteit vir jare gedy en is dit selfs deur die kerk gelegitimeer. Onderdanigheid word as 'n deug aan vroue voorgehou en gevolglik is vroue in die kerk, maar ook deur die kerk in ander kontekste van hul menswaardigheid gestroop en wat seksualiteit betref tot objekte gereduseer. Vir baie lank het ' $n$ fundamentalistiese interpretasie van die Bybel hierdie geslagsideologie gehandhaaf. Die onderdrukking van die vrou en die dominering deur die man is vandag nog springlewendig in die tradisioneel ortodokse, Afrikaanse konteks, en die Bybel word geweld aangedoen ten einde hierdie onreg as Bybelse norm te regverdig.

Oor die algemeen word seksualiteit in ' $n$ baie negatiewe lig beskou en vir baie lank was dit 'n verbode onderwerp, veral in die kerk. Seksualiteit en geslagsgemeenskap is ook onderwerp aan die onbillike en (in die meeste gevalle) onrealistiese etiek dat alle huwelikse seks wonderbaarlik en 'n gawe van God is, maar dat alle voor-huwelikse seks boos en promisku ${ }^{1}$ is.

\section{IS DIE BYBEL NOG GESAGHEBBEND?}

Die Evangelie van Johannes maak deel uit van die Nuwe Testament wat deur die Christendom as kanoniek aanvaar word. Die gesag van hierdie dokumente is geleë in die vermoë daarvan op ' $n$ appèl tot die individu te rig. Deur die inherente waarde van die teks word aanspraak gemaak op die leser se respek en gehoorsaamheid (McClintock 1995:54). Dit beteken egter nie dat antwoorde op etiese of lewenskwessies bloot simplisties afgelees kan word nie (Van Zyl 2002:235), maar die tekste moet teen die agtergrond van destydse gebruike en opvattings verstaan word om by daardie sake uit te kom wat fundamenteel is vir ' $n$ Christelike etiek wat steeds in ons hedendaagse konteks van toepassing is. Wanneer ons egter die Nuwe Testament nader ten einde 'n etiek vir seksualiteit daar te stel loop ons ons vas teen twee groot struikelblokke. In die eerste plek is daar nie ' $n$ etiek wat vir almal ewe veel gesag sal hê nie, en in die tweede plek is die Nuwe Testament ook nie 'n handboek vir morele kwessies nie. Aangesien die studie waarop hierdie artikel gebaseer is, vanuit die reformatoriese tradisie onderneem word, word ad fontes gewerk. Die Bybelteks is die vertrekpunt van elke argument wat in die studie waaroor hierdie artikel verslag doen, aangevoer is, maar die Bybelteks word uit die aard van die saak geproblematiseer, en die kanon agter die kultuur waarin die Bybelteks ingebed is, moet ontdek word.

\section{DIE SOEKE NA 'N VERANTWOORDBARE ETIEK}

Die problematiek waarmee die studie waaroor hier verslag gedoen word, te make gehad het, is dat die Nuwe Testament nie ' $n$ eksplisiete etiek oor geslagsrolle, die huwelik of seksualiteit aanbied nie. Verhey (1995:32) toon aan dat die Bybel in baie gevalle ' $n$ stilte handhaaf oor die kwessies wat in ons samelewing etiese en morele brandpunte is. Daarmee saam moet eerlike ondersoekers van die Bybel erken dat die Bybel deur mense geskryf is wat uit ' $n$ bepaalde agtergrond en ' $n$ bepaalde konteks kom en dat hierdie mense in 'n spesifieke taal skryf vir 'n spesifieke gehoor wat hulle in 'n bepaalde geografiese, kulturele en sosiale opset bevind wat dikwels baie ver verwyderd is van ons hedendaagse post-moderne opset. Daar is ' $n$ bepaalde 'vreemdheid' aan Bybelse tekste wat deur eerlike eksegete erken moet word.

Aan die ander kant het aansprake oor die gesag van die Bybel al dikwels onomkeerbare skade aangerig (Verhey 1995:32). Die Bybel is in die verlede ingespan om die patriargale konteks waarin 
hierdie tekste ontstaan het te legitimeer en gevolglik die onderdrukking en misbruik van vroue te substansieer. Om die Bybelteks so te gebruik doen die teks geweld aan en is nie in ooreenstemming met die groter boodskap en etiek wat deur die Bybel aangevoer word nie. Om eerlik met die Bybelteks om te gaan, vereis dus getrouheid en kreatiwiteit aan die kant van die eksegeet (Verhey 1995:36). Hierdie getrouheid en kreatiwiteit behels dat daarteen gewaak moet word om tekste etnosentries te lees wat die teks reduseer tot ' $n$ eksentrieke anachronisme wat uiteindelik bloedweinig sê vir vandag se gelowiges.

\section{'N MOONTLIKE VOORSTEL VIR KRITIESE NADENKE}

Die hipotese wat vir die studie waaroor hier gerapporteer word, aangebied is, was dat die Johannese tekste as gesaghebbende, kanonieke dokumente ' $\mathrm{n}$ inherente transformerende potensiaal het wat van toepassing gemaak kan word op die praktiese lewens van gelowiges (Mouton 1997:244). Vanweë die Bybelse tekste se ingebedheid in die patriargale waardesisteem van die antieke Mediterreense wêreld word ' $n$ hermeneutiek van suspisie hier 'n noodsaaklikheid. In die wisselwerking tussen die Bybelse teks en die hedendaagse konteks ontstaan daar egter 'n kreatiewe spasie wat vra om 'n voorlopigheid wat die tydelike aard van alle geloofsuitsprake erken (Mouton 1997:253). Hierdie voorlopigheid is ook nodig sodat die ervaring van ' $n$ lewende God wat altyd weer in nuwe kontekste tot openbaring kom, beleef kan word. Dit vra soms dat daar verby die patriargale aard en taal van hierdie tekste beweeg word na 'n meer inklusiewe taal, maar belangriker nog, na ' $n$ meer inklusiewe denkraamwerk. Die Bybelse dokumente bind ons nie op 'n rigiede, wettisistiese wyse nie, maar bevry ons vir die waardering van die genesende krag van God se helende genade in elke nuwe konteks. Ten spyte van die patriargale ingebedheid van hierdie tekste word ons uitgenooi om op ' $n$ paradoksale wyse deur lyding deel te verkry aan die triomf van Christus en om verby die stereotipiese beskouings van die mensheid te breek en te leer om die ander deur die oë van Christus te sien.

Die doel van die studie waarop hierdie artikel gebaseer is, was om die etiek, wat veral baie prominent in die Evangelie van Johannes voorkom, naamlik dat liefde tot God en liefde tot die naaste die enigste werklike kriterium vir 'n Christelike etiek is, op geslagsrolle, die huwelik en seksualiteit van toepassing te maak. Die argument is dat agape ' $n$ ononderhandelbare voorwaarde vir enige seksuele verhouding behoort te wees. Nie alle heteroseksuele huwelike slaag noodwendig hierdie toets nie. Die gedagte dat alle voorhuwelikse seks verkeerd is en alle binne-huwelikse seks reg is, kan eenvoudig nie meer sonder probleme aanvaar word nie. Die waardes en die houdings wat die verhouding definieer en die integriteit van die verhouding bewaar is van veel groter belang. Hierdie waardes sluit in liefde, respek, onselfsugtigheid, selfloosheid, vertroue, eksklusiwiteit, kontinuïteit, akkommodering, respek en verantwoordelikheid. Wat die Bybel oor die huwelik in sy antieke Mediterreense konteks sê, is ook nie naastenby gelykstaande aan wat vandag in die post-moderne Westerse konteks onder die begrip 'huwelik' verstaan word nie. Daarbenewens is die Bybel in werklikheid glad nie preuts oor seksualiteit nie. Dit is 'n gawe van God wat geniet behoort te word en dit is allermins iets om oor skaam of skuldig te voel.

Die huidige studie het beoog om aan te toon dat, wanneer die Bybelse tekste wetenskaplik binne hulle sosiale en kulturele konteks bestudeer word en daar uiteindelik by die retoriek en teologisering van die outeur uitgekom word, die Bybelse boodskap die heil van God vir die wêreld deur Jesus Christus verkondig en dat die strewe van elke Christen-gelowige in hulle etiek behoort te wees om Christus se deernis, barmhartigheid, regverdigheid, versoening en selflose liefde in interpersoonlike verhoudings uit te leef. Gerhardsson (1981:104) skryf dat die Evangelie van Johannes, in ooreenstemming met die Sinoptiese Evangelies, agape verhef tot die sentrale gebod waarin liefde tot God in verband gebring word met liefde tot die naaste. Burridge
(2007:326) skryf dat die Johannes-evangelie die grootste klem op die horisontale implikasie van hierdie gebod plaas. 'Ek gee julle 'n nuwe gebod: julle moet mekaar liefhê. Soos Ek julle liefhet, moet julle mekaar ook liefhê' (Johannes 13:33). Daar is hier geen vertikale ekwivalente opdrag met betrekking tot liefde tot God nie. Hierdie nuwe gebod word tydens die Laaste Avondmaal aan die dissipels gegee, nadat Jesus hulle voete gewas het. Hierdie konteks suggereer iets van die selfopofferende, totale gee van die self aan die ander en die daadwerklike optrede wat deur agape bedoel word. Verder skryf Burridge (2007:327) dat die navolgers van Jesus alleenlik tot hierdie daad van liefde in staat is omdat Jesus hulle eerste liefgehad het. In Johannes 15:12-13 ‘Dit is my opdrag: Julle moet mekaar liefhê soos Ek julle liefhet. Niemand het groter liefde as dit nie: dat hy sy lewe vir sy vriende aflê' word die opdrag herhaal en word die daad van selfoorgawe weer eens eksplisiet gemaak deur dit in verband te bring met Jesus se kruisdood. Dit gaan dus nie in die Johannes-evangelie om die vervulling van die wet of oor die altruïsme wat in die Sinoptiese Evangelies aangetref word nie (vgl. die gelykenis van die barmhartige Samaritaan), maar oor die feit dat Jesus eerste liefgehad het soos wat Hy dit gedemonstreer het deur die voete van sy dissipels te was en uiteindelik aan die kruis te sterf (kyk Nissen 1999:201-203; Hays 1996:144-146). Wat liefde dus in die Evangelie van Johannes beteken, kan teruggevind word in die voorbeeld van Jesus. Wat hierdie gebod 'nuut' maak, is volgens Collins (1986:116) die nuwe motief wat daaragter lê, naamlik die Christologie van Johannes. Ons het nie lief bloot om 'n gebod na te kom of om te reageer op 'n etiese appèl nie; ons het lief as gevolg van wat Christus reeds gedoen het. Die etiese lewe van 'n Christen is altyd 'n respons op dit wat Christus gedoen het.

Hierdie waardes of etiek kan inderdaad ook op 'n huweliksverhouding van toepassing gemaak word en dit geld uiteraard ook vir intieme verhoudings buite die huwelik. Omdat die etiek van Johannes in sy Evangelie by uitstek die etiek ten opsigte van die 'nuwe familie van God' wat in Jesus Christus tot stand gekom het en die nuwe gebod van agape is, het ek in die studie daarop gefokus om die Johannese etiek op interpersoonlike, heteroseksuele verhoudings van toepassing te maak.

\section{METODOLOGIE}

\section{'n Sosiaal-wetenskaplike lees van die teks}

Die opvatting dat alle idees, begrippe en kennis sosiaal bepaal word, moet op ' $n$ wetenskaplike wyse ernstig opgeneem word (Van Aarde 1992:437). Eksegete maak toenemend van sosiaalwetenskaplike teorieë gebruik om die dinamiek van mense, groepe en kulture in die antieke Mediterreense wêreld beter te begryp, te beskryf en te verklaar (Van Aarde 2007a:50).

Wetenskaplik beskou verwys die agtergronde waarteen tekste ontstaan ook na sosiale gedrag, sosiale groeperinge, sosiale instellings, sosiale stelsels, gedragskodes, ensovoorts. (Van Eck 1995:82). Verder word tekste gevorm deur die taal, inhoud en sosiale perspektiewe waarin hulle ontstaan. Uiteindelik word tekste die medium waardeur gekommunikeer word. Hierdie tekste kommunikeer ook iets van die sosiale agtergrond waarteen dit ontstaan het. Wat dus nodig is, is om verder te gaan as die insameling van onafhanklike historiese en sosiale data en om die interrelasie van idees en gemeenskaplike gedrag en waardestelsels en kultuurstelsels in ag te neem in verhouding tot die teks. Elliott (1989:5-6) toon aan dat die sosiaal-wetenskaplike lees van tekste twee fokuspunte het. Die eerste maak gebruik van die sosiale wetenskap om teorieë en modelle te vorm om die data te analiseer, wat lig werp op die antieke Mediterreense wêreld en die vroeë Christelike gemeenskap en wêreld. Die tweede fokuspunt is daarop gerig om lig te werp op die retoriese strategie wat deur die outeur met die teks beoog is binne die sosiale opset waarin dit ontstaan het. 'n Sosiaal-wetenskaplike lees van tekste ondersoek dus ook die narratiewe wêreld van die teks, die kommentaar wat die outeur 
lewer op die sosiale konteks. Van Aarde (2007a:50) skryf dat sosiaal-wetenskaplike kritiek as eksegetiese benadering fokus op die antieke Mediterreense kultuur en die sosiale interaksies wat bepalend was vir hierdie kultuur. Dié benadering het ten doel om die sosiale agtergrond van die dokumente in die Bybel te analiseer en die retoriek in die boodskap van die dokumente te begryp in die lig van hierdie kultuur. Die doel van die sosiaalwetenskaplike lees van tekste is juis om die retoriese effek van die teks binne die oorspronklike sosiale konteks daarvan vas te stel. In hierdie studie het die volgende sake aandag geniet: sosiale marginalisasie (kyk Duling 2003); die simboliese universum (kyk Joubert 1992a; 1992b); sosiale identiteit en groepformasie (kyk Malina 1995); 'anti-samelewing' (met ander woorde die 'subversiewe' aard van Jesus en sy eerste volgelinge) (kyk Malina \& Rohrbaugh 1998:7) en gesinswaardes (kyk Balch \& Osiek 1997)

Peterson (1985:6) stel ook 'n kombinasie van die literêre en die sosiaal-wetenskaplike metode voor aangesien dit aandag verleen aan beide die literêre of retoriese aspekte en die sosiologiese aspekte van 'n teks. Hierdie twee metodes in kombinasie, hoewel onderskeibaar, is weliswaar onskeibaar en albei essensieel tot ' $n$ omvattende begrip van ' $n$ teks. Tog behoort die literêre analise die sosiaal-wetenskaplike lees van die teks vooraf te gaan. Die rede hiervoor is dat die sosiale en die historiese konteks nie vir ons direk toeganklik is nie en hoogstens deur navorsers ge(re)konstrueer kan word, en vir hierdie rekonstruksie is 'n literêre analise noodsaaklik (Van Staden 1991:33). Van Aarde (2007a:52) stel dit ook dat die sosiaal-wetenskaplike lees van 'n teks die eksegeet help om te waak teen die eksegetiese fout van anachronisme, naamlik om dinge wat kronologies eers later in die geskiedenis sosiale verskynsels geword het, in ' $n$ tyd toe dit nog nie bestaan het nie, as sosiale verskynsels in tekste te veronderstel. Eksegete behoort in ag te neem dat die Bybel meer as twee duisend jaar gelede in 'n homogene agrariese gemeenskap ontstaan het, terwyl die hedendaagse realiteit dié van 'n geïndustrialiseerde post-moderne 'wêrelddorp' is (Van Aarde 2007a:65).

Horrel (2005:22-24) stel dat 'ideologiekritiek' bydra tot' $n$ sosiaalwetenskaplike, kritiese lees van die teks. Horrel verwys hier na die feministiese en bevrydingsteoloë as ' $n$ hermeneutiek van suspisie of 'betrokke hermeneutiek' (Van Aarde 2007c:1125). Hierdie soort hermeneutiek vra na die sosiale toestande van die mense waarna die teks verwys asook van diegene wat die teks ontvang en daaraan blootgestel word. Met 'sosiale toestande' word verwys na daardie faktore wat 'n individu of groep beïnvloed, en dit sluit faktore soos geslag, seksuele oriëntasie, ouderdom, etnisiteit, klas, status, nasionaliteit, politieke, kulturele en religieuse affiliasies en taal in (Van Aarde 2007c:1126)

Die insig van Peter Berger, in sy boek wat in 2004 verskyn het, Questions of faith: A skeptical affirmation of Christianity, verdien ten slotte om hier vermeld te word. Vir Berger word sosiale realiteite dialekties deur ' $n$ simboliese wêreld beïnvloed. Hy noem die simboliese wêreld die sacred canopy of 'heilige koepel' (vgl. Van Aarde 2007c:1132) wat mense se sosiale idees, ook dié van teoloë en eksegete, vanuit die transendente beïnvloed. Volgens Berger is kultuur dan dit wat oorbly ten opsigte van idees, denke, waardes, emosies en geloof op 'n abstrakte vlak, indien dit van alle konkrete handeling ontneem is. Kultuur vorm dus ' $n$ teoretiese abstraksie wat die wesenlike van menswees beïnvloed. Hierdie simboliese universum gee aanleiding tot die daarstelling van 'n sosiale universum waarbinne hierdie kultuur tot uiting kom. Die kultuur wat in die wêreld bedryf word, word dus dialekties gevorm deur die simboliese universum (Van Aarde 2007c:1133).

Die dialektiese denke in die filosofie, teologie en sosiologie wat kennis geneem het van die spanningsveld wat bestaan tussen die simboliese universum en die sosiale universum, het uiteindelik die insig na vore gebring dat kultuur as relatief tot' $n$ bepaalde periode, geografiese ligging en denkraamwerk gesien moet word. Binne hierdie dialektiek, waarskynlik in die soeke na orde en om 'n greep op die sosiale universum te kry, vind mistifisering plaas. Tydens die mistifiseringsproses word norme as kanoniek geïnternaliseer en gesosialiseer. Hierdie norme raak maklik geyk en dit dra daartoe by om sosiale identiteit te skep, en dit het gesag omdat dit as goddelik gesanksioneer word. Hierdie proses geskied veral met groot gemak in die sogenaamde 'boekgodsdienste' soos die Judaïsme, Islam en Christendom omdat die norme as geopenbaarde absolute waarhede in heilige tekste vervat word (Van Aarde 2007c:1136). Wanneer tekste egter kultuur-krities gelees word, word dit betwyfel of ' $n$ betekenisvolle lewe noodwendig sinoniem is met sosiale konformiteit. Berger noem hierdie blindelingse onderdanigheid aan die kultuur met betrekking tot geloofsake bad faith omdat gemistifiseerde natuurimperatiewe Bybels gelegitimeer word as God se wil. Kultuurkritiek bevraagteken die tradisionele en die konvensionele en aanvaar dit nie sonder meer as 'goddelik' nie (Van Aarde 2007c:1137). Dit is juis wat die huidige studie beoog het: om die tradisionele, geykte en konvensionele benaderings krities te bevraagteken. Dit is in ooreenstemming met die Reformatoriese tradisie wat deur die eeue heen die waagmoed geopenbaar het om menslike prestasie te relativeer, die onvermoë van die mens ruiterlik te erken en absolute vertroue in God te plaas. Wanneer teologie verburgerlik word, verloor dit hierdie self-kritiese aspek en 'n té positiewe houding word teenoor die mens se denke en dade ingeneem.

Die huidige studie wou aantoon hoe radikaal krities Jesus teenoor die kultuur van sy dag gestaan het. Die lewe van Jesus was nie geforseerd of kunsmatig nie, Hy was bloot kind van sy tyd. Van die begin van Jesus se openbare optrede vind ons by Hom 'n spanning tussen sy profetiese rol (kyk Danhauser 2006) en die dominante kultuur van sy dag. Hierdie spanning maak uiteindelik van Jesus 'n gemarginaliseerde Jood, wat buite die binnekring van die gevestigde Joodse tempelkultuur staan. Jesus pas nie in enige van die konvensionele sosiale rolle van sy dag in nie. Indien Jesus Homself wel met 'n sosiale groepering geassosieer het, was dit met mede-gemarginaliseerdes, medeuitgeworpenes. Dit getuig van Jesus se radikale toewyding aan God en sy hartstogtelike verbintenis aan die waarheid van die evangelie (Van Aarde 2007c:1140-1141).

In die geskiedenis van die mensheid is Jesus dus vir ons 'n voorbeeld van hulle wat nuwe dimensies vir menslike eksistensie open, wat mense van hulle eie tyd en kultuur is en in hulle eie taal uiting gee aan hulle kultuur, maar ook bo hulle kultuur uitstyg en te midde van hulle eie generasies nuwe fasette van menswees ontdek en vir wie daar in die woorde van NP van Wyk Louw (1958:65) 'vir elkeen van ons, tussen die engtes, 'n dieper, meer ingewikkelde dink ontstaan as waarmee ons tot dusver tevrede was'. Behoort elke navolger van Jesus Christus nie hierna te streef nie?

\section{HERMENEUTIESE IMPLIKASIES VIR DIE HUWELIK IN 'N POST-MODERNE KONTEKS}

Volgens Van Eck (2007a:81) is die huwelik as instelling in die moderne samelewing in ' $n$ krisis. Verder is die leiding wat die kerk in hierdie verband bied, dalk in 'n groter krisis, veral wat betref die stilswye van die kerk en die gebrek aan leiding ten opsigte van saamwoonverhoudings en voorhuwelikse seksuele kontak (vgl. Dreyer \& Van Aarde 2007a:625; Dreyer 2006:18) en sekere fundamentalistiese sieninge oor die huwelik wat nie op 'n verantwoordelike wyse uit die Skrif afgelei kan word nie (vgl. Craffert 2006:20). Die post-moderne begrip van die huwelik verskil radikaal van die uitbeelding van die huwelik soos ons in die Bybel aantref. Dit beteken egter nie dat riglyne oor die huwelik soos wat dit in die lewens van gelowiges behoort neerslag te vind, nie in die Skrif te vinde is nie (Van Eck 2007a:82). Dit is immers net so onmoontlik as'n ondubbelsinnige, absolute waarheid. Dreyer en Van Aarde (2007a:626) is van mening dat die wegdoen van sosiaal gekonstrueerde absolute waarhede ons van vermeende sekerhede ontneem en hierdie hermeneutiek wat kultuur-krities aan die werk is, 'n wesenlike bydrae kan maak om ons 'absolute' sienings oor die huwelik krities in oënskou te neem. 
Die huwelik in die tyd van Jesus was in die eerste plek 'n sosiale instelling met regsimplikasies. Gebruike en wette rakende die huwelik word beïnvloed deur die norme en waardes van ' $n$ samelewing en die kultuur van so 'n samelewing (De Villiers 2006). Dit problematiseer verder die gedagte dat die huwelik per se 'n Goddelike instelling is. Dit is immers ' $n$ feit dat nie net Christene nie, maar alle mense uit alle godsdienste wel in die huwelik tree en dat dit ook eeue voor die ontstaan van die Christelike godsdiens die geval was. Die meeste mense wat erns met hulle godsdiens maak, wil ook graag 'n goddelike seën oor hulle huweliksverbintenis laat uitspreek. Die geldigheid van die huwelik is egter ' $n$ wetlike en 'n geregtelike saak, terwyl die seremoniële en godsdienstige gebruike van kultuur tot kultuur sal verskil (De Villiers 2006).

Die post-moderne huwelik word verstaan as ' $n$ intieme liefdesverhouding tussen twee mense (Van Eck 2007a:82). Sake soos kameraadskap, die deel van ervarings, wedersydse liefde en vertroue kenmerk 'n gelukkige huwelik in ons samelewing. Twee individue word 'een' en albei die partye se persoonlikhede en gawes word tot voordeel van die ander aangewend sonder dat die individualiteit van een van die twee partye opgehef word. Daarbenewens is die keuse van 'n huweliksmaat 'n hoogs individuele aangeleentheid (Van Eck 2007a:83), Ooreenstemming ten opsigte van waardes en gemeenskaplike belangstellings weeg veel swaarder as kulturele agtergrond, hoewel kulturele, sosiale en ekonomiese agtergrond steeds ' $n$ rol speel.

Die ideale post-moderne huwelik is anti-patriargaal wat beteken dat albei partye as gelyke vennote funksioneer. Dit behels verder ' $n$ herdefiniëring van rolle, wat beteken dat beide die man en die vrou op gelyke vlak 'n bydrae tot die verskillende fasette van die huwelik kan maak. 'n Versmelting tussen die huishoudelike en die openbare sfeer is ook duidelik sigbaar. Vroue volg deesdae ook professionele loopbane, terwyl mans huishoudelike take verrig.

Die problematiek waarmee ons te kampe het wanneer daar sinvol oor die dialektiek tussen die Bybel as Woord van God (wat as gesaghebbend en normerend vir die lewe van die Christen-gelowige beskou word) en die eksistensiële ervaring van gelowiges in Suid-Afrika in 2009 nagedink word, is tweërlei. In die eerste plek bring die toepassing van ' $n$ verantwoordelike eksegetiese model ' $n$ mens tot die besef van die kloof ten opsigte van taal en kultuur wat tussen ons wêreld en die wêreld van die teks bestaan. Tweedens blyk dit dat die tradisionele waardes en norme wat uit die Bybel afgelei is en op huwelike van toepassing gemaak word, mense in hulle ervaring van die huwelik ontnugter het. Adrian Thatcher (1999:9) is van mening dat die inkongruensie tussen die ervaring van die huwelik en die 'teologie van die huwelik' deur die eeue heen problematies was (vgl. Dreyer 2007:2; Dreyer \& Van Aarde 2007a:629). Hierdie probleem lê volgens Thatcher (1999:15) nie by die Bybel nie, maar by die lesers van die Bybel. Die lesers van die Bybel behoort te soek na interpretasies van die Bybel wat alle mense se lewens kan verryk en hulle iets van die onvoorwaardelike liefde van Christus kan laat verstaan. Rosemary Haughton (1987:149) noem dat die teologie van die huwelik deur mense se ervaring daarvan vernietig word.

'n Fundamentalistiese lees van die Bybel en die sogenaamde 'Bybelse huwelik' is eenvoudig nie meer haalbaar nie en bied nie bevredigende antwoorde op die intense vrae wat in die harte van gelowiges brand en wat in hulle eie ervarings hierdeur ontnugter is nie. Tog is en bly die huwelik as 'n sosiale en ' $n$ geregtelike instelling vandag in Suid-Afrika steeds gewild. ' $n$ Mens kan maar net na die magdom huweliksbevestigingsplekke en huwelikskoördineerders wat bemark word en die geweldige pryse daaraan verbonde kyk om genoegsame getuienis hiervan in ons samelewing te vind. Die ontnugtering is egter net so groot wanneer die statistiek vir huwelike wat ontbind word in aanmerking geneem word. Te veel heteroseksuele huwelike word nog gedefinieer deur geweld, onderdrukking, verkleinering, misbruik en gedwonge seksuele omgang. Hoe word hierdie probleme op 'n verantwoordelike teologiese wyse die hoof gebied?

Van Wyk (2002:265) bepleit 'n dringende herbesinning oor die Christelike begrip van die huwelik en die rol wat die kerk hierin te speel het. Die beeld van die huwelik in die media laat mense deesdae nog minder in die haalbaarheid daarvan as ' $n$ konteks vir harmonieuse en gelukkige saamgroei glo aangesien huweliksontrou, verbale en fisiese geweld en verwaarlosing aan die orde van die dag is. Een uit elke twee huwelike eindig in die egskeidingshof (vgl. Thatcher 1999:10).

Van Wyk (2002:268) erken ook dat die formele aspekte ten opsigte van die instelling van die huwelik en die sluiting daarvan in die ontstaan en funksionering daarvan aanvanklik suiwer kultureel van aard was. Tog interpreteer die Kerk die huwelik as 'n 'instelling' en 'n 'gawe' van God (vgl. Ordereël 7 - Kerkorde van die NHK). Die groot vraag wat hier gevra behoort te word, is of die Kerk korrek is met die interpretasie dat die huwelik 'n instelling van God is aangesien die uitgangspunt oor die huwelik as gawe en instelling van God nie eksplisiet in die Bybel voorkom nie. Vir ' $n$ Kerk in die Reformatoriese tradisie wat wil erns maak met die Bybel as bron vir 'n Christelike lewenswyse en etiek, is dit van kardinale belang om eerlike antwoorde op hierdie kwellende vrae te bied. Dit is juis in hierdie verband waar die perspektief van biskop Spong (1988:177) nuttig is, naamlik dat die kerk'n ruimte moet bied vir paartjies om hulle voorneme om in 'n toegewyde, eksklusiewe verhouding met mekaar saam te leef, openlik te verklaar. Dreyer en Van Aarde (2007b:658-659) toon egter aan dat hierdie beskouing ook nie sonder probleme is nie omdat die verantwoordelikheid van die kerk ten opsigte van die beëindiging van so 'n verhouding en die liturgiese status van hierdie verklaring onseker is. Dreyer en Van Aarde (2007b:659) se voorstel dat die voorneme van so ' $n$ paartjie wel op 'n kerklike, ordelike wyse kan plaasvind, sonder noodwendig 'n liturgiese seremonie. Dit hou wel die voordeel in dat mense van onnodige skuldgevoelens bevry word. Kerklike kontrole oor hierdie aangeleenthede behoort nooit ' $n$ inkwisisie te word nie. Die kerk moet eerder die integriteit en eerbaarheid van mense wat tot so 'n stap wil oorgaan respekteer en pastoraal ondersteun.

Nadat die 'vreemdheid' van die Bybelteks aan ons wêreld verantwoordelik verdiskonteer is en die problematiek van die diskrepansie tussen 'n 'teologie van die huwelik' en die manifestasie daarvan in die praktyk erken is, sou ' $n$ moontlike antwoord hierop wees, in aansluiting by Van Wyk (2002:275), dat die primêre gesindheid wat in die evangelie aan huweliksgenote gestel word, dieselfde gesindheid is wat daar in Jesus Christus was. Ons vind dit soos ' $n$ refrein in die Evangelie van Johannes: soos die Vader Christus gestuur het, stuur Hy sy dissipels (vgl. Johannes 17:18); soos die Vader Hom liefgehad het, het Hy sy dissipels lief en so moet hulle mekaar ook liefhê (Johannes 15:9). Hierdie gesindheid behels selfopoffering, selfprysgawe en verloëning van die self, ten alle koste - selfs tot die dood toe (Van Wyk 2002:276). Wallace (2006:73) noem ook dat die hoër, oorkoepelende etiek die liefde is, die liefde van Christus wat die kanon agter die kanon vorm (vgl. Dreyer en Van Aarde (2007a:641). Waar hierdie gesindheid nie by mense te vinde is nie, word nie aan die eise van die evangelie voldoen nie. Wanneer die mens uit selfsug na selfbehoud en selfgeldendheid strewe en sy eie belang soek bo dié van die ander, daar is die mens ongehoorsaam aan God. Wanneer die eis van die evangelie, naamlik die radikale omgee vir die ander, nie nagekom word nie, is mense ontrou aan God. Om die belange van die ander bo dié van die self te stel is ' $n$ baie sterker Bybelse imperatief met betrekking tot die huwelik as die gewraakte uitdrukkings soos dat die man die hoof van die huis is, dat die man die hoof van die vrou is soos wat Christus die hoof van die kerk is, dat die vrou aan die man onderdanig moet wees en dat die vrou die swakker geslag is (kyk Efesiërs 
5). Die beginsel van selflose oorgawe aan die ander persoon is immers ' $n$ universeel evangeliese waarde wat vandag nog net so van toepassing is in post-moderne huweliksverhoudings waar 'n groter klem op gelyke vennootskappe geplaas word. Müller (2002:31) stel die volgende as norme waaraan ' $n$ huwelik eerder getoets behoort te word: wederkerigheid, duursaamheid, vryheid en veiligheid. Dit is inderdaad ' $n$ tragedie dat vele heteroseksuele huwelike nie aan hierdie kriteria voldoen nie. Verder is die heteroseksuele huwelik van vandag alles behalwe 'Bybels'. Daar bestaan immers nie iets soos ' $n$ 'Bybelse huwelik' nie, omdat daar meer as een huweliksvorm in die Bybel aangetref word - poligamie was immers selfs tot in die koningstydperk van Israel die algemeen aanvaarde norm!

Uiteindelik is dit die evangelie wat uit die Bybel moet weerklink en nie die kulturele agtergrond daarvan nie. Die universele boodskap van die evangelie spreek tog vandag tot die harte van mense en dwing mense om hul persoonlike lewens volgens die waardes van die evangelie in te rig.

\section{Hermeneutiese implikasies vir geslagsideologie}

'n Mens kan die vraag vra hoe daar hoegenaamd enige waarde geheg kan word aan die algemeen aanvaarde beskouing dat die Christelike geloof manlike dominansie voorstaan. 'n Eerlike ondersoek na die agtergrond waarteen die Christendom ontstaan het, toon dat die patriargale stelsel waarin hierdie tekste ontstaan het, in die teks neerslag gevind het. Die kultuur van die Bybel of die agtergrond waarteen die Bybel ontstaan het, is nie bo kritiek verhewe nie. Dit blyk in elk geval dat die vroeë Jesus-beweging in spanning geleef het met die eer-skaamtekodes van die dag en dit blatant uitgedaag en ontmasker het (Browning 2004:3). Die vroeë Christendom was duidelik in konflik met die kultuur van die dag wat geslagskwessies betref. Binne die Jesus-beweging is vroue bemagtig en opgehef. Die belangrikste beginsel in die vroeë Christelike gemeentes was gelykwaardigheid - die gebod van om jou naaste lief te hê soos jouself en dit moes ook die hartklop van die familielewe en die verhouding tussen man en vrou uitmaak.

Die selfverloëning van die kruis is nie die doel opsigself nie, maar probeer liefde as gelykwaardige beginsel herstel wanneer dit in ' $n$ krisis verkeer of uit balans is (Browning 2004:8). So word beide man en vrou geroep om die kruis van selfverloënende liefde te dra in diens aan mekaar en in diens van die gelykwaardige behandeling van albei geslagte.

Stewart van Leeuwen (2004:14) voel so sterk oor die afwysing van die leer van manlike dominansie dat sy dit gelyk stel aan die dwaalleer van apartheid omdat dit die bron is van soveel misbruik van vroue en omdat soveel onreg in die naam daarvan aan vroue gedoen is.

'n Ondersoek na die historiese konteks bring aan die lig dat iets splinternuuts deur die Jesus-beweging ingelui is wat beide die manier van dink en die praktyk geraak het omtrent die verhouding tussen man en vrou (Osiek 2004:26).

'n Verantwoordelike poging om getrou te wees aan 'n Bybelse visie is om te doen wat die eerste Christene gedoen het en om die vroeë Christelike beweging voort te sit in die rigting van volkome gelykwaardigheid. Vandag beteken enige iets minder as gelykwaardigheid ' $n$ miskenning van die persoon van die vrou. ' $n$ Letterlike interpretasie van die Bybelteks buite die konteks daarvan lei tot 'n verarming daarvan. Net so kan 'n oorbeklemtoning van die analogie van Christus as die hoof van die kerk, soos wat die man die hoof van die vrou is, totaal irrelevant raak. Wanneer ' $n$ analogie of metafoor geyk raak, wys dit nie meer na iets groters nie en verloor dit die vermoë om iets van die misterie van God te openbaar (Osiek 2004:27).

Miller-McLemore (2004:61) wys daarop dat die aksent op die manlike onderdanigheid deur die eeue heen onderbeklemtoon is. In stede daarvan het vroue veel eerder die boodskap van selfverloëning en onderdanigheid geïnternaliseer. Wanneer mans egter die evangelie gehoor het, het hulle minder dominant geword en meer toegeeflik.

Scanzoni en Hardesty (1992:110) voer aan dat die terme 'manlik' en 'vroulik' deur kultuur gedomineer word. Dit word van toepassing gemaak op nie alleen menslike gedrag nie, maar ook op die take wat aan die verskillende geslagte opgedra word. So word daar gepraat van ' $n$ 'man se werk' en ' $n$ 'vrou se werk'. Tog het kulturele antropoloë aangetoon dat daar in sommige gemeenskappe mans is wat uitsluitlik die taak verrig van kook, weef, klere maak en mandjies vleg terwyl die vroue die taak het om huise te bou, landbou te beoefen, vee op te pas en vis te vang. Ons kan dus tot die gevolgtrekking kom dat die mens besonder aanpasbaar is, maar dat ons dit word wat die gevolg is van ons kulturele omgewing. Individue leer 'n geslagsidentiteit op ' $n$ baie vroeë ouderdom aan en dit word aangeleer deur met 'n ouer van dieselfde geslag te identifiseer en deur volwassenes te imiteer. Soos kinders groot word, ontvang hulle gedurig boodskappe oor hoe seuns en dogters veronderstel is om op te tree. In plaas daarvan om mense universeel as persone te beskou, word hulle van kleins af gekondisioneer - selfs met die kleure wat hulle aangetrek word wanneer hulle babatjies is. Seuntjies dra blou en dogtertjies dra pienk.

Die kerk keur nie alleen hierdie onderskeid wat deur die samelewing getref word goed nie, maar moedig dit ook aan. ' $n$ Kind merk baie vinnig op dat die meeste leidende posisies in die kerk deur mans beklee word.

Wanneer ons God se plan met die mensdom probeer verstaan, moet ons by die doel begin: die eenheid van alle mense in Christus. Die kerk moet hierdie doel aktualiseer en hierdie gemeenskaplike realiteit moet in elke persoon beslag vind. Deel daarvan is om te verstaan wie mans en vroue in Christus is.

Ons moet dus gaan kyk na wat die Nuwe Testament leer oor ons lewe in Christus en daaruit moet ons aspireer vir 'n lewe wat menswaardigheid na alle mense bring. Dit bring egter ' $n$ persoonlike verantwoordelikheid mee, 'n diepe persoonlike toewyding wat van elke gelowige geëis word. Dit is by uitstek die verantwoordelikheid van die kerk aangesien die kerk die lig van die nasies moet wees. Die wêreld behoort die oplossings vir die dilemmas wat ontstaan deur hierdie nuwe bewuswording van menswaardigheid in die gemeenskap van die gelowiges raak te sien. Daarom is die rol van feminisme hier belangrik want dit wys ons op die kerk se onvermoë om die basis van die probleem te verstaan of om die eise daarvan uit te leef. Wanneer feminisme dus sekere onregte in die kerk uitwys, behoort daar daarna geluister te word. Die kerk moet homself kan verwoord op sekere vrae wat kan ontstaan, aangesien blatante of latente diskriminasie teen vroue in Christelike kerke vandag soms steeds volgehou word op grond van die 'kerklike tradisie'.

Hans Küng (2001:95) rig in hierdie verband die onderstaande kritiese vrae aan die kerk:

Op grond waarvan weier die Ortodokse en die RoomsKatolieke kerke steeds die gelyke deelname van die vrou in hul aktiwiteite en ook ten opsigte van die bediening? Gegee die leidende rol wat vroue in die vroeë kerk gespeel het (bv. Phoebe en Prisca/Priscilla) en die totaal ander posisie van die vrou vandag in die sakewêreld, gemeenskap, onderwys en kultuur, kan die toelating van die vrou tot die amp nog langer uitgestel word? Was Jesus en die vroeë kerk nie juis hulle tyd vooruit in hul evaluering van die vrou nie, naamlik dat kerke wat voortgaan om die vrou te weier eintlik agter die evangelie is? Is dit nie tyd om, in die gees van die evangelie, die praktyk van diskriminasie teen vroue te beëindig en aan hulle ook die waardigheid te bied wat hulle in die kerk toekom nie?

Küng (2001:97) voer verder aan dat die kerk in die gees van sy Stigter 'n gemeenskap van vryheid, gelykheid en broederskap (susterskap) moet wees. In die eerste plek is die kerk ' $n$ gemeenskap van hulle wat vry is. Die kerk behoort 
nooit weer gekenmerk te word as 'n plek van verdrukking of onderdrukking waar een groep mense bo 'n ander verhewe is nie. Hierdie vryheid moet in die kerk sigbaar wees, maar dit moet ook na die wêreld toe gekaats word. Tweedens moet die kerk in beginsel 'n plek wees waar almal gelyk is. En laastens moet die kerk 'n gemeenskap van broers en susters wees. Dit is dus glad nie legitiem vir 'n kerk om patriargaal of paternalisties te wees nie. Wanneer dit dus kom by die bekleding van die ampte kan daar nie de facto teen die vrou gediskrimineer word nie. Die beginsel van broederskap behoort immers beslag te kry in die gestruktureerde orde van die kerk. Die kerk behoort gesien te word as 'n plek waar broederskap (en dus ook susterskap) bevorder word.

In haar werk Feminism and Christian ethics betoog Susan Parson (1996:222) vir 'n beweging in die rigting van 'n nuwe humanisme. Vroue moet bevry en bemagtig word ten einde groter vervulling in die menslike bestaan teweeg te bring. Sy beklemtoon dat feministiese denke uiteindelik ' $n$ moreeletiese doel nastreef. Dit beliggaam 'n kritiese ingesteldheid en evaluering van bestaande morele stelsels. 'n Hoop op bevryding en vervulling staan sentraal in die feminisme. Deur die ontdekking van 'n nuwe humanisme waarin man en vrou beide herken word as na die beeld van God geskape en bedoel vir gemeenskap met mekaar en met God, mag feminisme dalk haarself transendeer om die hoop en die toekoms te bied wat dit beloof

\section{Hermeneutiese implikasies vir die begryp van egbreuk en seksualiteit}

Lisa Sowle Cahill (1995:5) skryf dat, wanneer na Bybelse riglyne oor seksuele etiek gesoek word, teoloë dikwels vasval in reëls wat seksuele gedrag reguleer. Die taak van die kritiese teoloog is vandag eerder om die oorspronklike sosiale agtergrond waarteen die Bybelse uitsprake ontstaan het na te vors en om die oorspronklike betekenis vir die bedoelde gehoor vas te stel. Eers dan kan die ooreenkomste en verskille met die hedendaagse konteks verdiskonteer word. Omdat Cahill die teks vanuit 'n feministiese perspektief benader, kies sy 'n hermeneutiek van suspisie wat baie fyn trap om nie die seksuele etiek wat uit die Bybel begrond word te verwar met die instandhouding van patriargale maatskaplike konvensies nie. Hierdie benadering maak dit moontlik om meer holisties na seksuele verhoudings te kyk in die lig van gelykheid, insluiting en emansipasie sonder om te verval in 'n liberale modus van individualisme, outonomiteit en vryheid (Cahill 1995:10).

Cahill (1995:10) noem verder die baie belangrike aspek dat alle seksuele verhoudings in die voor-Christelike Romeinse wêreld beheer is deur 'n patriargale hiërargie waar baie streng norme gegeld het rakende die verkiesing van die regte vrou en die inrigting van die huwelik sodat die voortbestaan van die familie gewaarborg kan word. Alle seksuele verhoudings het 'n sosiale doel gedien en was in byna elke opsig die simbool van manlike dominansie. Binne die Christelike opset is hierdie dominansie egter opgehef: die gemarginaliseerdes is ingesluit die armes is versorg, vroue en slawe is by die gemeenskap van gelowiges ingesluit en ' $n$ nuwe manier van lewe is geïnisieer, hoewel dit nooit in volmaaktheid bereik is nie (Cahill 1995:11).

Brayford (1999:168) verduidelik dat die eer-skaamte-model lig werp op die inherente geslagsideologie wat agter hierdie sosiale konvensies skuil. Die seksualiteit van die vrou moet in toom gehou word ten einde die man se eer te beskerm sodat hy nie in die openbaar tot skande gebring word nie. Ten einde die moontlikheid hiervan te beperk, word die man die heerser in die seksuele arena en so verseker hy dat sy manlike eer ten alle koste beskerm word. Die onderdanige vrou verkry deel aan die eer van die man, indien sy haarself daaraan onderwerp.

As gevolg van die twee uiteenlopende paradigmas enersyds deur die massamedia (wat 'n absolute liberalistiese en individualistiese beeld van seksualiteit voorhou), en 'n onderdrukkende geslagsideologiese patriargale eer-skaamte- paradigma (wat deur die kerk in stand gehou word) andersyds, voel baie mense verskeurd en is dit vir hulle onmoontlik om outentiek te leef. So word die kerk uiteindelik die agent van negatiewe skaamte in plaas van Goddelike eer.

Hierdie studie sluit aan by Cahill en Brayford se hermeneutiek van suspisie, wat verby die sosiale konvensies wat die teks verduister, breek en die evangeliese motiewe wat daaragter lê, ontsluit. Die toneel wat in Johannes 8 geskets word, moet as't ware weer afspeel en vra: 'Wat het Jesus werklik hieroor gesê?'

Dit sluit aan by Loader (2005:45) wat aanvoer dat seksualiteit per se nêrens in die Nuwe Testament aangeval word nie. Seksualiteit per se is immers net so moreel of immoreel soos hande, voete of oë. Die vraag is wat ons met hierdie seksualiteit doen en watter houdings teenoor die naaste ingeneem word. Wat die Nuwe Testament wel sê oor seksualiteit en die uitleef daarvan is in ons post-moderne konteks nog net so relevant, want dit handel oor die houdings en die intensies wat ons gedrag bepaal. Dit is die punt wat Jesus ook in Matteus 5:28 maak. Indien egbreuk sonde is, dan is elke gesindheid van begeerte en wat die bedoeling daartoe het, ook sonde. Jesus verskuif die fokus van die daad na die gesindheid wat die daad motiveer en die gesindheid waarin die daad gepleeg word. Loader (2005:45) toon verder aan dat hierdie verskuiwing van fokus ook later daartoe lei dat die klem van die daad na die persoon verskuif. Gevolglik word die vraag gevra na die gedagtes en bedoelinge agter die daad en of dit tot die persoon se toekomstige welstand sal lei. Seksualiteit is immers ' $n$ baie persoonlike aangeleentheid en omvat die hele persoon en raak nie net die persoonlike welstand van die self nie, maar ook hoe ander deur hierdie optrede geraak word. Die studie ondersteun Loader (2005:46) se standpunt dat hierdie fokus op houding die ryke potensiaal het vir 'n etiese ondersoek na seksualiteit. Dit lei ons weg van die vraag of 'n spesifieke daad reg of verkeerd is. Hoe dikwels gebeur dit nie dat 'n getroude paartjie mekaar verontreg en onmeetlike skade aandoen sonder dat 'n daad van egbreuk ooit gepleeg is nie. 'n Oorbeklemtoning van die daad van egbreuk laat ons die gevaar loop om nie die oorsake wat daartoe aanleiding kon gee, te verdiskonteer nie. Fundamenteel is die imperatief wat ons uit die evangelies kan aflei dat interpersoonlike verhoudings gekenmerk moet word deur liefde en respek. Indien ons hierdie imperatief ernstig opneem, word seksuele etiek 'n houding van liefde en omgee vir die ander, en dan is enige iets wat nadelig is vir die ander in stryd met die wil van God. Dit is nie die samelewing of die geslagsideologie wat die finale oordeel hieroor mag fel nie. Die kriteria wat móét geld, is dié van liefde en omgee en die soeke na die beste belang van die ander. So ook moet die legitimiteit al dan nie van 'verbode' seksualiteit hieraan gemeet word. Dit het juis die ontwikkeling van 'n verantwoordelike en eerlike seksuele etiek vir baie lank aan bande gelê omdat sekere seksuele taboes absoluut was en uit die aard van die saak is dit nooit krities nagedink of bevraagteken nie. Hierdie taboes het veels te dikwels ook gruwelike geweld en misbruik in stand gehou.

Die evangelie van Jesus Christus doen 'n dieper en voller verstaan van die seksuele aan die hand wat ons verby die verdedigingsmeganismes van die tradisionele neem na 'n liefde wat altyd die beste belang van die naaste soek.

Die primêre oorweging ten opsigte van egbreuk sentreer deesdae óm die verraad en die verbreking van die intieme vertroue tussen twee individue. Die liefdesgebod gaan verder as om net huwelikstrou toe te pas en nie aan egbreuk skuldig te wees nie. Dit beteken ' $n$ diepgaande besorgdheid oor die welstand van die ander.

Volgens Loader (2005:55) bring die evangelie van Jesus Christus 'n verdere belangrike aspek rakende die seksualiteit van mans en vroue na vore. Die stereotipe dat die vrou en haar seksualiteit vir die man 'n bedreiging inhou en selfs dat die vrou gevaarlik is, het tot gevolg gehad dat daar streng maatreëls voorgestel is ten einde die seksualiteit van die vrou in te perk. Die evangelie beklemtoon egter dat die man ook 'n verantwoordelikheid in hierdie verband het. Waar vroue as potensieel gevaarlik 
gesien is, mag die sfere waarin mans en vroue beweeg ook nie oorvleuel het nie. Vaders moes hulle dogters tuis hou, en vroue moes hulle op so 'n manier klee dat hulle nie die mans in die versoeking sou lei nie.

Jesus se optrede is hier radikaal anders. Hy sluit vroue onder sy volgelinge in en herstel hulle menswaardigheid. Jesus betoon selfs solidariteit aan die kwesbare vroue en beskou hulle nóg as 'n potensiële gevaar nóg as seksuele objekte.

Die Bybel praat egter nêrens eksplisiet oor die kwessie waarmee die post-moderne teoloog gekonfronteer word nie, maar wat wel uit die wasigheid duidelik word, is baie meer as wat ' $n$ mens met die eerste lees van die teks raaksien. Matteus 5:28 stel dat elke man wat na 'n vrou kyk en haar begeer, in sy hart reeds skuldig is aan egbreuk. Hierdie stelling impliseer nie dat vroue gevaarlik is nie, maar dat mans verantwoordelikheid moet aanvaar vir hulle eie dade. Die stelling val nie seksualiteit per se aan nie, maar plaas dit binne konteks. Wat Jesus oor egbreuk te sê het, is 'n verdieping van die gebod. Die gebod word geïntensiveer na die houdings en die gesindhede wat bepalend is vir die optrede. Daar kan tot die gevolgtrekking gekom word dat 'n gesonde en gelukkige post-moderne huwelik nie noodwendig 'n huwelik is waarin egbreuk nie voorkom nie, maar eerder een waar die waardes wat Jesus onderrig het, sentraal staan. Dit sluit in om respek te hê vir die menswaardigheid van die ander en om die ander so lief te hê soos jouself. Menige huwelik, hoewel vry van egbreuk, slaag nie hierdie toets nie en is uiteindelik destruktief omdat hierdie waardes ontbreek.

Vervolgens noem Peter Vardy (1997:171) in sy boek The Puzzle of Sex vier beginsels wat ons in die rigting van seksuele etiek kan begelei (vgl. Dreyer \& Van Aarde 2007b:655):

- Seksualiteit is 'n wesenlike deel van die menslike natuur en hang ten nouste af van die ervarings wat 'n individu as kind beleef het en die moontlikheid om liefde te gee en te ontvang en sinvol in seksuele verhoudings betrokke te raak.

- 'n Benadering tot seksuele etiek behoort die persoon in totaliteit in ag te neem.

- Seksuele omgang moet altyd 'n vrywillige daad wees, die gawe van intimiteit, toewyding en vertroue van een outonome individu aan 'n ander. Die plesier wat hiermee gepaard gaan, is bloot die byproduk en nie die doel opsig self nie.

- Om liefde te maak behoort 'n diepe misterieuse ervaring tussen twee individue te wees. Klem op die meganika van die daad en deur die konteks van die verhouding waarbinne dit plaasvind te ignoreer, lei daartoe dat die ware betekenis daarvan verlore gaan.

Vir mense wat 'n vaste, wettiese paradigma soek om oor seksualiteit te praat, kan bogenoemde riglyne 'n struikelblok wees, maar dan moet daar weer eens in gedagte gehou word hoe Jesus nie gekies het vir 'n wettiese uitspraak nie, maar vir die pastorale begeleiding van die individu. Op hierdie punt beklemtoon Vardy (1997:174) ook dat die evangelie van Jesus Christus 'n geweldige appèl rig tot die verantwoordelikheid van die individu wat daarop reageer. Die evangelie van Jesus Christus roep mense tot 'n uiters hoë persoonlike verantwoordelikheid vir hulle eie menswaardigheid asook die menswaardigheid van ander. Binne hierdie benadering is dit uiteindelik die gehalte van ' $n$ verhouding wat belangrik is en nie die wettiese definisie daarvan nie.

\section{SLOTOPMERKINGS}

Die liefdespel is sekerlik een van die genotvolste en kreatiefste ondernemings van die mensheid. Maar vir té lank het hierdie liefdespel vanweë die dominansie van die partriargale stelsel plek gemaak vir 'n jagter-bokkie-paradigma waar van die vrou verwag is om passief, kuis en ingetoë te wag dat daar op haar 'jag gemaak' word. Wanneer sy dan 'gevang' is, moes sy haarself vrywillig oorgee aan haar veroweraar wat dan met haar as sy trofee kon pronk.
Waar twee individue egter as gelykwaardige vennote aan 'n mistieke liefdespel deelneem, word ander moontlikhede vir menslike vervulling moontlik. Wanneer die selfsugtige 'ek-moet-ten-alle-koste-oorwin'-paradigma plek maak vir 'n dienskneggestalte, 'n gestalte van die ander se belang bo dié van my eie, 'n gestalte van diepe verwondering en waardering vir die persoon en die menswees van die ander met wie ek in ' $n$ intieme situasie verkeer, word groot moontlikhede van ekstase en vervulling ontsluit wat tot op hede vir die meeste ongekend was. Dit sal myns insiens ook tot 'n groter harmonie en verweefdheid tussen liggaam, siel, verstand en gees lei en seksuele behoeftes behoort nie langer in konflik met diepe geloof te staan nie. Lewe in al sy fasette kan dan in sy volheid ervaar word en liefde tot God en liefde tot die naaste word in die mees intieme verhouding tussen twee individue' $n$ konkrete werklikheid.

\section{LITERATUURVERWYSINGS}

Balch, D.L. \& Osiek, C. (reds.), 1997, Early Christian families in context: An interdisciplinary dialogue, Grand Rapids, Eerdmans.

Beasley-Murray, G.R., 1999, Word Biblical commentary: John, 2de uitgawe, Thomas Nelson Publishers, Nashville.

Berger, P.L., 2004, Questions of faith: A sceptical affirmation of Christianity, Blackwell, Malden, MA

Brayford, S.A., 1999, 'To shame or not to shame: Sexuality in the Mediterranean diaspora', Semeia 87, 163-175.

Browning, D., 2004, 'The problem of men', in D. Blankenhorn, D. Browning \& V.L.M. Stewart (reds.) Does Christianity teach male headship? The equal-regard marriage and its critics, p. 3-12, Eerdmans, Grand Rapids.

Burridge, R.A., 2007, Imitating Jesus: An inclusive approach to New Testament ethics, William B Eerdmans Publishing Company, Grand Rapids.

Cahill, L.S., 1995, 'Sexual ethics: A feminist Biblical perspective', Interpretation 49(1), 5-15.

Collins, R.F., 1986, Christian morality: Biblical foundations, Universiteit van Notre Dame, Notre Dame, IN.

Countryman, L.W., 1988, Dirt, greed and sex: Sexual ethics in the New Testament and their implications for today, Fortress Press, Philadelphia.

Craffert, P.F., 2006, 'Godsdiensaktueel: Wat sê die Bybel van die huwelik? [Religion: What does the Bible say about marriage?]' Beeld, 3 Desember, 2006, p. 20.

Dannhauser, E.H., 2006, 'Jesus the Prophet: Maps and memories', PhD-verhandeling, Universiteit van Pretoria.

Deissmann, G.A., 1927, Light of the Ancient Near East: The New Testament illustrated by recently discovered texts of the GraecoRoman world, vertl L.R.M. Strachan, Doran New York.

Dreyer, A.E. \& Van Aarde, A.G., 2007a, 'Bybelse modelle van die huwelik: 'n Kritiese perspektief [Biblical models of marriage: A critical perspective]', HTS Teologiese Studies/ Theological Studies 63(2), 625-651.

Dreyer A.E. \& Van Aarde, A.G., 2007b, "n Krities-hermeneutiese perspektief op die huwelik in 'n post-moderne era [A criticalhermeneutical perspective on marriage in postmodern times]', HTS Teologiese Studies/Theological Studies 63(2), 653681.

Dreyer, T.F.J., 2007, 'Die kerk, huwelik en seks [The church, marriage and sex]', rede gelewer tydens die eerste VTTsessie van 2007.

Dreyer, Y., 1999, 'Jesus en vroue [Jesus and woman]', HTS Teologiese Studies/Theological Studies 55(1), 70-96.

Dreyer, Y., 2006, 'Godsdiensaktueel: Huwelik dra swaar bagasie [Religion: Heavy burden on marriage]', Beeld, 17 Oktober 2006, p. 18.

De Villiers, G,. 2006, 'Die Huweliksformulier: teologies nagedink [The Conduct of Marriage: A theological thought]' besigtig 16 November 2006, by www.teo.co.za

Duling, D.C., 2003, The New Testament: History, literature and social context, Thompson Wadsworth, Toronto.

Elliot, J.H., 1989, 'Social-scientific study of the Bible and the biblical world', ongepubliseerde referaat gelewer tydens ' $n$ M-Div-seminaar van die Departement Nuwe Testament, Fakulteit Teologie, Universiteit van Pretoria, 4 April. 
Elliot, J.H., 1991, A home for the homeless: A sociological exegesis of 1 Peter, its situation and strategy, 2de uitgawe, Fortress Press, Minneapolis.

Gerhardsson, B., 1981, The Ethos of the Bible, Fortress Press, Philadelphia.

Haughton, R., 1987, 'The meaning of marriage in women's new consciousness', in W.P. Roberts (red.), Commitment to partnership: Explorations of theology of marriage, n.p., Paulist Press, New York.

Hays, R.B., 1996, The moral vision of the New Testament: A contemporary introduction to New Testament ethics, HarperSanFrancisco, San Francisco.

Horrel, D.G., 2005, Social-scientific interpretation thirty years on: Prospect (and retrospect), referaat gelewer tydens die 'Social Scientific Criticism section of the Society of Biblical Literature' vergadering, Philadelphia, Verenigde State, November 20, 2005, p.

Joubert, S.J., 1992a, 'Van werklikheid tot werklikheid: Die interpretasie en interkulturele kommunikasie van Nuwe Testamentiese waardes [From reality to reality: The interpretation and intercultural communication of New Testament values]', Scriptura 41, 55-65.

Joubert, S.J., 1992b, 'Wanneer die onmoontlike moontlik word: Paulus as verkondiger en bouer van 'n nuwe universum [When the impossible becomes possible: Paul preacher and builder of a new universe]' Nederduitse Gereformeerde Teologiese Tydskrif 33, 301-310.

Karen, R., 1992,'Shame', The Atlantic monthly, Februarie, p. 40-70

Kerkorde van die Nederduitsch Hervormde Kerk van Afrika, datum, titel, Ordereël 7 p. 89-91.

Küng, H., 2001, Women in Christianity, Continuum, New York.

Loader, W., 2005, Sexuality and the Jesus tradition, William Eerdmans Publishing Company, Grand Rapids.

Louw, N.P. van Wyk, 1958, Liberale nasionalisme: Gedagtes oor die nasionalisme, liberalisme en Tradisie vir Suid-Afrikaners met 'n kulturele nadrup [Liberal Nationalism: Thoughts on the nationalism, liberalism and tradition for South Africans with a cultural after effect], Nasionale Boekhandel Bpk, Kaapstad.

Malina, B.J., 1995, 'Early Christian Groups: Using small group formation theory to explain Christian organisations', in P.J. Esler (red.), Modelling early Christianity: Social-scientific studies of the New Testament in its context, pp. 96-113, Routledge, Londen.

Malina, B.J. \& Rohrbaugh, R.L., 1998, Social science commentary on the Gospel of John, Fortress Press, Minneapolis.

Marshall, H.I., 2004, New Testament theology: Many voices, one gospel, Intervarsity Press, Downers Grove.

McClintock, M., 1995, 'Church documents on human sexuality and the authority of Scripture', Interpretation (1), 46-58.

Meeks, W.A., 1983, The first urban Christians: The social world of the Apostle Paul, Yale University Press, New Haven, CT.

Miller-McLemore, B., 2004, 'A feminist Christian theologian looks (askance) at headship', in D. Blankenhorn, D Browning \& V.L.M. Stewart (reds.), Does Christianity teach male headship? The equal-regard marriage and its critics, pp. 49-62, Eerdmans, Grand Rapids.

Mouton, E., 1997, 'The transformative potential of the Bible as resource for Christian ethos and ethics', Scriptura (2), 243257.

Müller, J., 2002, Gesinne van binne [Families from within], Bloemfontein, Barnabas.

Nissen, J., 1999, 'Community and ethics in the Gospel of John', in J. Nissen \& S. Pedersen (reds.), New readings in John Literary and theological perspectives, Scheffield Academic Press, Scheffield.

Osiek, C., 1984, What are they saying about the social context of the New Testament?, Paulist Press, New York.

Osiek, C., 2004, 'Did early Christians teach, or merely assume, male headship?' in D. Blankenhorn, D. Browning \& V.L.M. Stewart (reds.), Does Christianity teach male headship? The equal-regard marriage and its critics, pp. 23-27, Eerdmans, Grand Rapids.
Parsons, S.F., 1996, Feminism and Christian ethics, University Press, Cambridge.

Parsons, S.F., 2000, Challenging women's orthodoxies in the context of faith, Ashgate, Burlington.

Peterson, N.R., 1985, Rediscovering Paul: Philemon and the sociology of Paul's narrative world, Fortress Press, Philadelphia.

Scanzoni, L.D., \& Hardesty, N.A., 1992, All we're meant to be: Biblical feminism for today, Eerdmans, Michigan.

Spong, J.S., 1988, Living in sin? A bishop rethinks human sexuality, Harper \& Row, San Francisco.

Stewart van Leeuwen, M., 2004, 'Is equal regard in the Bible?' in Blankenhorn, D. Browning \& V.L.M. Stewart (reds.), Does Christianity teach male headship? The equal-regard marriage and its critics, pp. 13-22, Eerdmans, Grand Rapids.

Thatcher, A., 1999, Marriage after modernity: Christian marriage in postmodern times, Sheffield Academic Press, Scheffield.

Van Aarde, A.G., 1992, 'The Evangelium infantium, the abandonment of children, and the infancy narrative in Matthew 1 and 2 from a social scientific perspective', Lovering, 435-453.

Van Aarde, A.G., 2007a, 'Inleiding tot die sosiaal-wetenskaplike kritiese eksegese van Nuwe Testamentiese tekste: Die metodologiese aanloop in die navorsingsgeskiedenis [Introducing the social-scientific critical exegesis of New Testament texts: Methodological initiators in the research history]', HTS Teologiese Studies/Theological Studies 63(1), 49-79.

Van Aarde, A.G., 2007b, ‘Die Sosiaal-wetenskaplike kritiese eksegese van Nuwe Testamentiese tekste: 'n Kritiese oorsig van die eerste resultate [The social-scientific critical exegesis of New Testament texts: A critical assessment of the first results]', HTS Teologiese Studies/Theological Studies 63(2), 515-542.

Van Aarde, A.G., 2007c, 'Sosiaal-wetenskaplike kritiese eksegese van Nuwe Testamentiese tekste: 'n Voortgaande debat sonder einde [Social-scientific critical exegesis of New Testament texts - an ongoing debate without end]', HTS Teologiese Studies/Theological Studies 63(3), 1119-1147.

Van Eck, E., 1995, Galilee and Jerusalem in Mark's story of Jesus: A narratological and social scientific reading, Promedia Printers, Pretoria.

Van Eck, E., 2007a, 'Die huwelik in die eerste-eeuse Mediterreense wêreld: Vroue in 'n man se Wêreld [Marriage in the first-century Mediterranean world (1): Females in a male world', HTS Teologiese Studies/Theological Studies 63(1), 81-101.

Van Eck, E., 2007b, 'Die huwelik in die eerste-eeuse Mediterreense wêreld: Huwelik, egbreuk egskeiding en hertrou [Marriage in the first-century Mediterranean world (II): Marriage, adultery, divorce and remarriage', HTS Teologiese Studies/Theological Studies 63(1), 103-128.

Van Staden, P., 1991, Compassion - the essence of life: A socialscientific study of the religious symbolic universe reflected in the ideology/theology of Luke, Tydskrifafdeling van die Nederduitsch Hervormde Kerk (HTS Suppl 4), Pretoria.

Van Wyk, D.J.C., 2002, 'Huwelik en seksualiteit in 'n postmoderne samelewing [Marriage and sexuality in a postmodern society', HTS Teologiese Studies/Theological Studies 58(1), 265-282.

Van Zyl, H.C., 2002, 'Die Nuwe Testament en seksualiteit [The New Testament and sexuality]', Acta Theologica (2), 234-261.

Vardy, P., 1997, The puzzle of sex, HarperCollins, Londen.

Verhey, A.D., 1995, 'The holy Bible and sanctified sexuality. An evangelical approach to Scripture and sexual ethics', Interpretation (1), 31-45.

Williams, R.H., 1997, 'The mother of Jesus at Cana: A socialscience interpretation of John 2:1-12', The Catholic Biblical Quarterly 59, 679-692.

Zimmermann, H., 1974, Neutestamentliche Methodenlehre: Darstellung der Historisch-kritischen Methode [New Testament Teaching Methods: Presentation of the historical-critical method] 4 de uitgawe, Verlag Katholisches Bibelwerk, Stuttgart. 